The Reign of Law 
This page intentionally left blank 


\title{
The Reign of Law
}

Marbury v. Madison and the

\section{Construction of America}

\author{
Paul W. Kahn
}

Yale University Press

New Haven and London 
Copyright $\odot 1997$ by Yale University.

All rights reserved. This book may not be reproduced, in whole or in part, including illustrations, in any form (beyond that copying permitted by Sections 107 and 108 of the U.S. Copyright Law and except by reviewers for the public press), without written permission from the publishers.

Library of Congress Control Number: 2002101074

ISBN 13: $978-0-300-08392-7$

A catalogue record for this book is available from the British Library.

The paper in this book meets the guidelines for permanence and durability of the Committee on Production Guidelines for Book Longevity of the Council on Library Resources. 
To my parents, Samuel and Elizabeth Kahn 
This page intentionally left blank 